A C T A UNIVERSITATIS NICOLA I COPER I C I DOI: http://dx.doi.org/10.12775/AUNC_ECON.2013.012 EKONOMIA XLIV nr 2 (2013) 159-175

Pierwsza wersja złożona 2 lutego 2013

\title{
STATYSTYCZNY OBRAZ BYDGOSKO-TORUNSKIEGO OBSZARU METROPOLITALNEGO NA TLE WYBRANYCH OBSZARÓW METROPOLITALNYCH W POLSCE WEDŁUG TYPOLOGII OECD
}

Z a ry s treści. W artykule poruszono kwestie delimitacji i zróżnicowania obszarów metropolitalnych w zakresie zagadnień demograficzno-społecznych i ekonomicznych w Polsce, ze szczególnym uwzględnieniem Bydgosko-Toruńskiego Obszaru Metropolitalnego. Podstawę analiz stanowiły wybrane, ujęte w statystyce publicznej obszary metropolitalne w $2010 \mathrm{r}$. Do oceny ich wewnętrznego zróżnicowania posłużono się typologią OECD, która pozwoliła w ujęciu jednostek funkcjonalnych ukazać skalę procesów suburbanizacji.

S ł o w a k 1 u c z o w e: obszar metropolitalny, obszar wiejski, obszar miejski.

$\mathrm{K} 1$ as y fik a c j a J E L: O18, P25.

\section{WSTĘP}

Metropolia, obszar metropolitalny i metropolizacja są coraz powszechniej stosowanymi terminami dla określenia zależności funkcjonalno-przestrzennych miejskich układów osadniczych, które współcześnie staja się motorami rozwoju partycypującymi w globalnych procesach wymiany. Udział ten zależy przede wszystkim od pełnionych funkcji, na które współcześnie duży wpływ ma globalizacja. Przez np. zwiększoną ruchliwość i mobilność przestrzenną kapitału, towarów i ludzi oraz szybki rozwój cywilizacji technicznej wpływa ona na zmiany relacji przyczynowo-skutkowych

*Adres do korespondencji: Wiesława Gierańczyk, Urząd Statystyczny w Bydgoszczy, Oddział w Toruniu, ul. Mickiewicza 10/16, 87-100 Toruń, e-mail:w.gieranczyk@stat.gov.pl

(C) 2013 Uniwersytet Mikołaja Kopernika. All rights reserved. http://www.aunc.ekonomia.umk.pl 
przestrzeni zurbanizowanej. Kształtowana pod wpływem tych zjawisk kolejna, nowa i jakościowo inna faza urbanizacji znacznie różni się (tak pod względem ilościowym, jak i jakościowym) od wcześniej zachodzących procesów, ponieważ:

- jest związana, z obserwowanym w ostatnich dziesięcioleciach, szybkim wzrostem znaczenia dużych układów miejskich we współczesnej gospodarce,

- oznacza pewne odstępstwo od zasady hierarchicznej organizacji przestrzeni (teoria Christallera) - wnosząc nowe silne powiązania między odległymi ośrodkami metropolitalnymi, częściowo uniezależnia siłę oddziaływania ośrodka od jego „masy” i odległości fizycznej,

- zmienia relacje między miastem metropolitalnym a otaczającym regionem,

- oznacza nowy sposób terytorialnego podziału pracy, kapitału, wiedzy i władzy (Markowski, Marszał, 2006).

Powiązania i relacje jednostek osadniczych w ramach obszaru metropolitalnego skłaniają badaczy do hierarchizacji metropolii. Zakładając, że są produktami procesów globalnych, powinny być definiowane i klasyfikowane w nawiązaniu do ustaleń i standardów międzynarodowych. W związku z tym np. Jewtuchowicz (2004, s. 51-59) oraz Jałowiecki i Szczepański (2006, s. 210) wyodrębniają metropolie:

- światowe, odgrywające znaczną rolę w sterowaniu gospodarką w skali światowej,

- kontynentalne, których uczestnictwo w procesach umiędzynarodowienia jest kształtowane przez ponadnarodowe relacje regionalne,

- regionalne, będące ośrodkami o niekompletnie wykształconych funkcjach metropolitalnych, które odgrywają węzłową rolę w skali danego kraju lub kilku krajów sąsiednich.

Podejście całościowe nie wyklucza jednak uwzględniania specyficznych uwarunkowań krajowych przy delimitowaniu metropolii. Kryteria ich wyznaczania mogą w pewnym stopniu zależeć od stawianych celów i uwzględniać np. różnice regionalne wynikające ze specyficznych dla danego terytorium założeń polityki rozwoju systemu osadniczego.

\section{DELIMITACJA OBSZARÓW METROPOLITALNYCH}

W Polsce kwestie wyodrębnienia metropolii były podejmowane zarówno przez naukowców, jak i w dokumentach strategicznych. Zajmowali się nimi m.in. Dziewoński (1971), Maik (1975), Korcelli (1976, 1981), Rykiel (1985), Kuciński (1990), Chmielewski (1995), Gawryszewski, Korcelli, 
Nowosielska (1998), Jałowiecki (1999), Grzeszczak (1999), Jałowiecki (2000), Kołodziejski (2001), ESPON (2004), Trafas, Zborowski (2004), Gorzelak, Smętkowski (2005), Klimska, Swianiewicz (2005), Smętkowski, Jałowiecki, Gorzelak (2008), Heffner (2011), Śleszyński (2012). Z analizy tych opracowań wynika, że podstawowe znaczenie dla identyfikacji obszaru metropolitalnego ma procedura delimitacji jego zasięgu przestrzennego, w tym ustalenie i wybór mierników powiązań społecznych, a także relacji organizacyjnych i dostawczych między instytucjami. Powiązania społeczne i gospodarcze są najczęściej analizowane przy pomocy mierników mobilności ludności, tj. dojazdów do pracy, dojazdów młodzieży do szkół oraz mieszkańców stref podmiejskich do instytucji usługowych, a także migracji ludności na pobyt stały określanych czasem jako migracje definitywne (Korcelli, Potrykowska, Bodzak, 1981; Gocal, Rakowski, 1991; Zborowski, 2002).

Na przykład według Markowskiego i Marszała (2006), aby dane miasto można było zaliczyć do grona metropolii w warunkach polskich, powinno ono spełniać następujące kryteria:

- być względnie duże (min. 0,5-1 mln mieszkańców),

- posiadać znaczny potencjał ekonomiczny oraz silnie rozwinięty sektor usług wyższego rzędu,

- charakteryzować się dużym potencjałem innowacyjnym (jednostki naukowe i badawczo-rozwojowe),

- pełnić funkcje o charakterze metropolitalnym, tj. funkcje centralne wysokiego rzędu hierarchicznego o zasięgu co najmniej krajowym,

- odgrywać rolę węzła w systemie (sieci) powiązań komunikacyjnych, organizacyjnych i informacyjnych oraz charakteryzować się dużą dostępnością $\mathrm{w}$ różnych skalach przestrzennych, także w skali miedzynarodowej,

- stymulować rozwój sieciowego modelu gospodarki i zarządzania.

Według wspomnianych autorów wtórne w stosunku do wyżej wymienionych kryteriów funkcjonalnych pozostają cechy morfologiczne ośrodków metropolitalnych, a mianowicie:

- wykształcenie metropolitalnych układów przestrzennych z rozległą zurbanizowaną strefą podmiejską o silnych dośrodkowych powiązaniach integracyjnych,

- wyjątkowość i specyfika miejsca (zwłaszcza centrum miejskiego) ze względu np. na znaczenie historyczne, kulturalne czy walory architektoniczno-urbanistyczne. 
W dokumentach strategicznych kwestie metropolizacji porusza najnowsza Koncepcja Przestrzennego Zagospodarowania Kraju 2030 (KPZK 2030). Zaprezentowany w niej punkt widzenia wskazuje na odejście od idei rozwoju opartej na tezie zwornikowego położenia Polski w Europie na rzecz wizji rozwoju sieci powiązań funkcjonalnych krajowych ośrodków wzrostu połączonych z europejską (głównie zachodnioeuropejską) siecią metropolii. W dokumencie tym, na podstawie doświadczeń innych krajów oraz po przeanalizowaniu prac Europejskiej Sieci Obserwacyjnej Rozwoju Terytorialnego i Spójności Terytorialnej (ESPON), stwierdzono, że za metropolie można uznać te ośrodki (wraz z ich obszarami funkcjonalnymi), które:

- stanowią centra zarządzania gospodarczego na poziomie co najmniej krajowym,

- mają duży potencjał gospodarczy (ponadkrajową atrakcyjność inwestycyjna),

- oferują szereg usług wyższego rzędu i pełnią funkcje symboliczne,

- charakteryzują się wysoką zewnętrzną atrakcyjnością turystyczną dużymi możliwościami edukacyjnymi i innowacyjnymi (rozbudowane szkolnictwo wyższe, obecność jednostek naukowych i badawczo-rozwojowych),

- mają zdolność do utrzymywania relacji handlowych, naukowych, edukacyjnych, kulturowych z międzynarodowymi metropoliami,

- charakteryzują się wysoką wewnętrzną i zewnętrzną dostępnością transportową.

Warto zwrócić uwagę, że według badań porównawczych (np. ESPON) polskie miasta, oprócz Warszawy i w niektórych poszczególnych aspektach także Krakowa, Aglomeracji Górnośląskiej, Trójmiasta, Poznania, Wrocławia, mają słabo rozwinięte funkcje metropolitalne w porównaniu do miast podobnej wielkości w Europie Zachodniej. W związku $\mathrm{z}$ powyższym w KPZK 2030 na podstawie kryteriów odnoszących się głównie do funkcji miast $\mathrm{w}$ systemie osadniczym kraju, takich jak ${ }^{1}$ : liczba ludności w ośrodku metropolitalnym powyżej 300 tys. Mieszkańców, zatrudnienie w sektorze usług rynkowych (pośrednictwo finansowe oraz obsługa nieruchomości i firm) powyżej 40 tys., liczba studentów kształcących się w danym mieście w roku akademickim 2007/2008 powyżej 60 tys., współpraca instytucji naukowo-badawczych w 5. i 6. Programie Ramowym UE, lokalizacja portu lotniczego obsługującego ruch pasażerski, lokalizacja hoteli cztero- i pięciogwiazdkowych, międzynarodowe wystawy w obiektach działalności wysta-

${ }^{1}$ Dane za 2009 r. 
wienniczej w latach 2006-2008, wyznaczono ośrodki metropolitalne i ich obszary funkcjonalne dla: Warszawy, Aglomeracji Górnośląskiej (główny ośrodek Katowice), Krakowa, Łodzi, Trójmiasta, Poznania, Wrocławia, bipolu Bydgoszczy z Toruniem oraz Szczecina. W Lublinie wskazano cechy metropolitalności bez lokalizacji lotniska obsługującego ruch pasażerski. Ze względu jednak na swoje znaczenie rozwojowe, np. w zakresie potencjału akademickiego (duży ośrodek naukowy) i koncentracji działalności gospodarczej, oraz kontakty z krajami położonymi na wschód od Polski został zaliczony do ośrodków metropolitalnych. Pozostałe miasta wojewódzkie niespełniające powyższych kryteriów określono, jako ośrodki o znaczeniu krajowym - niemniej we wszystkich istnieje potrzeba wzmacniania funkcji metropolitalnych dla zapewniania bardziej równomiernego rozwoju kraju opartego o policentryczną sieć głównych miast (czyli metropolii, miast o znaczeniu krajowym i regionalnym). $Z$ tego względu obowiązek delimitacji obszarów funkcjonalnych, przygotowania planu zagospodarowania oraz strategii rozwoju dla całego obszaru funkcjonalnego dotyczy wszystkich miast wojewódzkich - niezależnie od ich roli w krajowej sieci osadniczej. Podstawą planu przestrzennego zagospodarowania i strategii rozwoju obszaru metropolitalnego jest zasada pierwszeństwa regeneracji (odnowy) zabudowy nad zajmowaniem nowych terenów pod zabudowę. Oznacza to intensyfikację procesów urbanizacyjnych na obszarach już zagospodarowanych, tak aby minimalizować ekspansję na nowe tereny. Elementem planu i strategii będzie również deglomeracja usług na całym obszarze metropolitalnym mająca na celu racjonalne nasycenie całego obszaru różnorodnymi funkcjami metropolitalnymi oraz usługami wyższego rzędu.

W toku administracyjnych dyskusji nad obszarami metropolitalnymi w Polsce i wobec braku ustawy metropolitalnej ich liczba i delimitacja budzą nadal wiele kontrowersji. Przygotowane do tej pory projekty aktów prawnych obszarów metropolitalnych zostały skrytykowane bądź przez jednostki samorządu lokalnego, bądź regionalnego. Wobec powyższego w niniejszym opracowaniu dla ukazania statystycznego obrazu Bydgosko-Toruńskiego Obszaru Metropolitalnego posłużono się delimitacją przyjętą przez urzędy statystyczne dla potrzeb przygotowania Statystycznego Vademecum Samorządowca (SVS) w 2011 r. z danymi rok 2010 r. Opracowania takie powstały dla: Aglomeracji Poznańskiej, Bydgosko-Toruńskiego Obszaru Metropolitalnego, Górnośląskiego Związku Metropolitalnego, Kieleckiego Obszaru Metropolitalnego, Krakowskiego Obszaru Metropolitalnego, Lubelskiego Obszaru Metropolitalnego, Obszaru Metropolitalnego Warszawy, Szczecińskiego Obszaru Metropolitalnego i Trójmiejskiego Obszaru Metropolitalnego. Podstawę ich wydzielenia stanowiły zawarte porozumienia gmin o wy- 
odrębnieniu takich obszarów. W woj. kujawsko-pomorskim porozumienie partnerskie $\mathrm{w}$ sprawie obszaru metropolitalnego o nazwie Bydgosko-Toruński Obszar Metropolitalny (BTOM) zawarły w 2008 r. powiaty: bydgoski i toruński, oraz miasta na prawach powiatu: Bydgoszcz i Torun. Wnikliwą analizę poglądów i koncepcji wyodrębniania obszaru o funkcjach ponadregionalnych wokół Bydgoszczy i Torunia przedstawił Maik (2010, s. $65-73)$.

\section{ZRÓŻNICOWANIE WEWNĘTRZNE BTOM I INNYCH OBSZARÓW METROPOLITALNYCH}

Próbę ukazania zróżnicowania wewnętrznego BTOM i pozostałych obszarów metropolitalnych ujętych w SVS przygotowano w oparciu o typologię regionalną OECD. Pozwala ona na rozróżnienie obszarów wiejskich i miejskich nie tylko według kryterium administracyjnego, ale także według gęstości zaludnienia i stopnia zurbanizowania. Identyfikowanie i podział regionów według tej typologii uwzględnia 2 poziomy analizy terytorialnej, tj. lokalny (dla Polski - gmina) i regionalny (dla Polski - TL 3, odpowiadający NUTS 3) i 3 etapy klasyfikacji:

1. Na poziomie lokalnym, jednostki administracyjne sklasyfikowane są jako miejskie lub wiejskie, według następujących kryteriów:

- obszar wiejski to obszar, gdzie gęstość zaludnienia nie przekracza 150 osób/ $\mathrm{km}^{2}$,

- obszar miejski to obszar, gdzie gęstość zaludnienia wynosi 150 lub więcej osób $/ \mathrm{km}^{2}$.

2. Na poziomie regionalnym jednostki funkcjonalne lub administracyjne klasyfikuje się w zależności od udziału ludności mieszkającej na obszarach wiejskich (według kryteriów poziomu lokalnego) jako regiony:

- przeważająco wiejskie - gdy więcej niż 50\% jego mieszkańców zamieszkuje obszary lokalne sklasyfikowane jako wiejskie według kryteriów poziomu lokalnego,

- pośrednie - gdy udział procentowy mieszkańców zamieszkujących obszary lokalne sklasyfikowane jako wiejskie wynosi $15-50 \%$,

- przeważająco miejskie - gdy mniej niż $15 \%$ jego mieszkańców zamieszkuje obszary lokalne sklasyfikowane jako wiejskie.

3. Dodatkowo na poziomie regionalnym obszary wiejskie definiowane sa w oparciu o kryterium wielkości populacji miasta, gdzie:

- region sklasyfikowany jako przeważająco wiejski staje się pośrednim, jeżeli na jego terenie położone jest miasto o liczbie ludności powyżej 200 tys., które koncentruje co najmniej 25\% populacji tego regionu, 
- region sklasyfikowany jako pośredni staje się przeważająco miejskim, jeżeli na jego terenie położone jest miasto o liczbie ludności powyżej 500 tys., które koncentruje co najmniej $25 \%$ populacji tego regionu.

Bydgosko-Toruński Obszar Metropolitalny terytorialnie pokrywa się z utworzonym 1 stycznia 2008 r. podregionem bydgosko-toruńskim, który według typologii OECD został zdefiniowany jako przeważająco miejski. Analiza jego wewnętrznej struktury w odniesieniu także do innych określonych porozumieniami obszarów metropolitalnych znajduje swoje uzasadnienie $\mathrm{w}$ potrzebie określenia istnienia i skali procesów suburbanizacyjnych wobec zwiększenia roli miast $\mathrm{w}$ generowaniu wzrostu gospodarczego. Określenie podobieństw funkcjonalnych obszarów pretendujących do rangi obszarów metropolitalnych jest kluczowe w planowaniu ich rozwoju.

W niniejszym opracowaniu pierwszy etap prac obejmował wybór zmiennych i zgromadzenie danych opisujących obszary metropolitalne. Zebrane zmienne diagnostyczne ze względu na swoją postać podzielono na 2 kategorie (zmienne strukturalne i wskaźniki), które pod względem merytorycznym ujmowały zagadnienia demograficzno-społeczne, gospodarcze i finanse jednostek samorządu terytorialnego. Następnie dokonano dwuetapowej analizy podobieństwa obszarów metropolitalnych, biorąc pod uwagę:

a) wewnętrzną strukturę funkcjonalną obszarów metropolitalnych wyodrębnioną w oparciu o kryteria przyjmowane przez OECD na pierwszym etapie typologii funkcjonalnej, określającym jednostki na poziomie lokalnym jako miejskie lub wiejskie,

b) poziom rozwoju społeczno-gospodarczego wyrażony wskaźnikami (zmienne relatywne).

W klasyfikacji podobieństwa miejskich i wiejskich obszarów w obszarach metropolitalnych zastosowano hierarchiczną metodę aglomeracyjną. $\mathrm{W}$ tej grupie metod proces skupiania bazuje na wewnętrznym kryterium podziału, jakim jest matematycznie zdefiniowane podobieństwo między obiektami. Klasyfikację $n$ obiektów rozpoczyna się od utworzenia $n$ jednoelementowych skupień, które w kolejnych $n-1$ krokach są łączone w następne skupienia, aż do uzyskania jednego skupienia zawierającego wszystkie obiekty. Miarą tego podobieństwa są odległości między grupami obiektów, które $\mathrm{w}$ tym opracowaniu mierzono za pomocą metryki euklidesowej. Do wydzielenia grup metropolii, wewnętrznie podobnych pod względem analizowanych zmiennych i jednocześnie różnych wobec siebie, użyto metody Warda (Grabiński, Sokołowski, 1984, s. 63-79).

W metodzie tej odległości między dwoma grupami nie można przedstawić wprost za pomocą odległości pomiędzy obiektami należącymi do tych grup. Dwie grupy obiektów przy tworzeniu połączeń są łączone w jedną 
grupę, tak aby zminimalizować sumę kwadratów odchyleń wszystkich obiektów, należących do tych dwóch grup, od środka ciężkości nowej grupy, która powstaje $\mathrm{w}$ wyniku połączeń tych dwóch grup. Oznacza to, że na każdym etapie łączenia grup ze wszystkich możliwych obiektów wiąże się w jedną grupę te grupy, które w rezultacie tworzą zespół obiektów o najmniejszym zróżnicowaniu ze względu na opisujące je zmienne.

Do analizy zróżnicowania obszarów metropolitalnych pod względem rozkładu potencjału społeczno-gospodarczego na obszarach miejskich i wiejskich użyto następujących zmiennych:

a) w sferze demograficzno-społecznej:

- ludność obszarów miejskich i wiejskich metropolii w \% (1a),

- ludność w wieku przedprodukcyjnym obszarów miejskich i wiejskich metropolii w \% (1b),

- ludność w wieku produkcyjnym obszarów miejskich i wiejskich metropolii w \% (1c),

- ludność w wieku poprodukcyjnym obszarów miejskich i wiejskich metropolii w \% (1d),

- powierzchnia $\mathrm{w} \mathrm{km}^{2}$ obszarów miejskich i wiejskich metropolii w \% (1e);

b) w sferze gospodarczej:

- pracujący na obszarach miejskich i wiejskich metropolii w \% (2a),

- bezrobotni na obszarach miejskich i wiejskich metropolii w \% (2b),

- podmioty wpisane do rejestru regon na obszarach miejskich i wiejskich metropolii w \% (2c),

- podmioty sektora prywatnego na obszarach miejskich i wiejskich metropolii $\mathrm{w} \%$ (2d),

- podmioty powyżej 50 pracujących na obszarach miejskich i wiejskich metropolii $\mathrm{w} \%(2 \mathrm{e})$;

c) w sferze budżetów jednostek samorządu terytorialnego (jst):

- wydatki ogółem jst na obszarach miejskich i wiejskich metropolii w \% (3a),

- wydatki majątkowe inwestycyjne jst na obszarach miejskich i wiejskich metropolii w \% (3b),

- dochody ogółem jst na obszarach miejskich i wiejskich metropolii $\mathrm{w} \%(3 \mathrm{c})$,

- dochody własne jst na obszarach miejskich i wiejskich metropolii w \% (3d),

- dochody od osób fizycznych i prawnych jst na obszarach miejskich i wiejskich metropolii w \% (3e). 


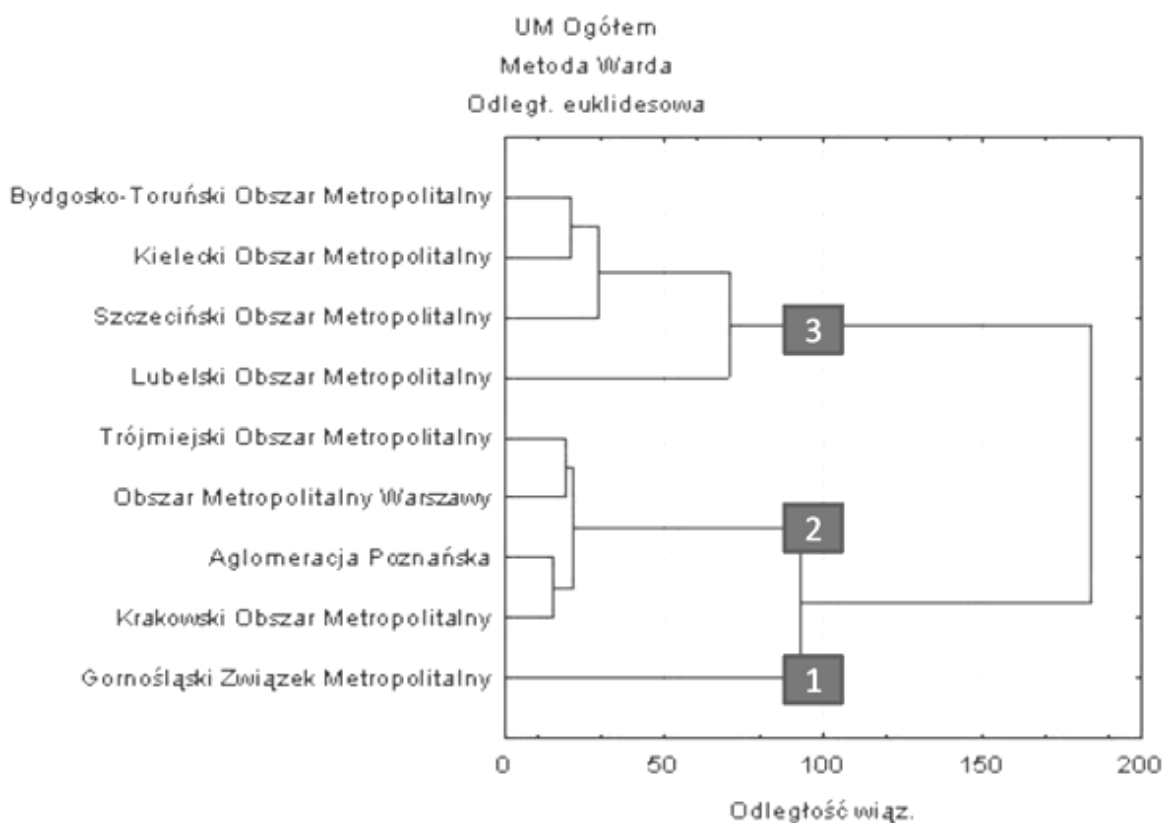

Rysunek 1. Dendrogram skupień obszarów metropolitalnych podobnych pod względem udziału zjawisk społeczno-gospodarczych na obszarach miejskich w $2010 \mathrm{r}$.

Źródło: opracowanie własne.

Tabela 1. Model średnich arytmetycznych skupień obszarów metropolitalnych podobnych pod względem rozkładu zjawisk społeczno-gospodarczych na obszarach miejskich w $2010 \mathrm{r}$.

\begin{tabular}{|c|c|c|c|c|c|c|c|c|c|c|c|c|c|c|}
\hline $1 \mathrm{a}$ & $1 b$ & 1c & $1 d$ & $1 \epsilon$ & $2 a$ & $2 b$ & $2 c$ & $d$ & $2 \mathrm{e}$ & 3a & 3b & $3 c$ & $3 d$ & $3 e$ \\
\hline $\mathrm{mon}$ & , & 100 & 1000 & 100, & $10 \mathrm{c}$ & 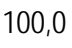 & $1 \mathrm{Mn}$ & Ins & D. & $10 \mathrm{c}$ & I & m & Ins & 20, \\
\hline 287,8 & 84,8 & 87,9 & 90,6 & 47,6 & 94,1 & 85,3 & 92,0 & 92,0 & 94,3 & 90,5 & 89,4 & 90,6 & 93,4 & 92,9 \\
\hline 73,8 & 9,1 & 4,1 & 7,3 & 18,4 & 86,3 & 1,6 & 81,4 & 81,6 & 87,6 & 76,9 & 67,7 & 77,7 & 82,1 & 81,8 \\
\hline
\end{tabular}

Źródło: obliczenia własne.

Przeprowadzona analiza podobieństwa obszarów metropolitalnych podobnych pod względem udziału zjawisk społeczno-gospodarczych na obszarach miejskich pozwala wyodrębnić 3 skupienia (rysunek 1), spośród których skupienie 1 obejmuje w pełni zurbanizowany Górnośląski Związek Metropolitalny, skupienie 2 obszary metropolitalne o wyraźnie wyższej niż średnio na analizowanych obszarach koncentracji potencjału społeczno- 
-ekonomicznego na obszarach miejskich, natomiast w skupieniu 3 udział obszarów miejskich wahał się od ok. $20 \% \mathrm{w}$ przypadku zajmowanej powierzchni (Lubelski Obszar Metropolitalny -6,1\%) do ok. 80\% w przypad$\mathrm{ku}$ koncentracji na obszarach miejskich podmiotu sektora prywatnego, podmiotów pow. 50 pracujących i dochodów od osób fizycznych i prawnych (tabela 1). Bydgosko-Toruński Obszar Metropolitalny wraz z obszarami metropolitalnymi: Kieleckim, Szczecińskim oraz Lubelskim, znalazł się w skupieniu 3, osiagając wyższą niż średnio w tym skupieniu koncentrację potencjału społeczno-ekonomicznego na obszarach miejskich.

Jako że na tym etapie analizowano rozkład zjawisk w ujęciu strukturalnym, przebieg aglomeracji podobieństwa obszarów metropolitalnych pod względem rozkładu zjawisk społeczno-gospodarczych na obszarach wiejskich był identyczny. Po wyłączeniu w pełni zurbanizowanego Górnośląskiego Związku Metropolitalnego wyodrębniono 2 skupienia, z których skupienie 1 objęło metropolie o niższej, zaś skupienie 2 o wyższej niż średnio $\mathrm{w}$ analizowanych obszarach metropolitalnych koncentracji potencjału społeczno-ekonomicznego na obszarach wiejskich.

W kolejnym etapie prac dokonano aglomeracji podobieństwa miejskich obszarów metropolitalnych, biorąc pod uwagę wartości wskaźników obrazujących natężenie zjawisk społeczno-gospodarczych:

a) w sferze demograficznej:

- gęstość zaludnienia (1A),

- wskaźnik obciążenia demograficznego (1B);

b) w sferze gospodarczej:

- pracujący na 1000 ludności (2A),

- udział bezrobotnych w ludności w wieku produkcyjnym w \% (2B),

- bezrobotni na 1000 mieszkańców (2C),

- podmioty wpisane na 10 tys. ludności (2D),

- udział podmiotów sektora prywatnego w podmiotach ogółem w (2E),

- udział podmiotów pow. 50 prac. W ogólnej liczbie podmiotów $\mathrm{W} \%(2 \mathrm{~F})$;

c) w sferze finansów publicznych:

- wydatki na 1 mieszkańca w zł (3A),

- wydatki majątkowe inwestycyjne w \% ogółu wydatków (3B),

- dochody na 1 mieszkańca w zł (3C),

- dochody własne na 1 mieszkańca w zł (3D),

- udział dochodów od osób fizycznych i prawnych w dochodach ogółem w \% (3E). 


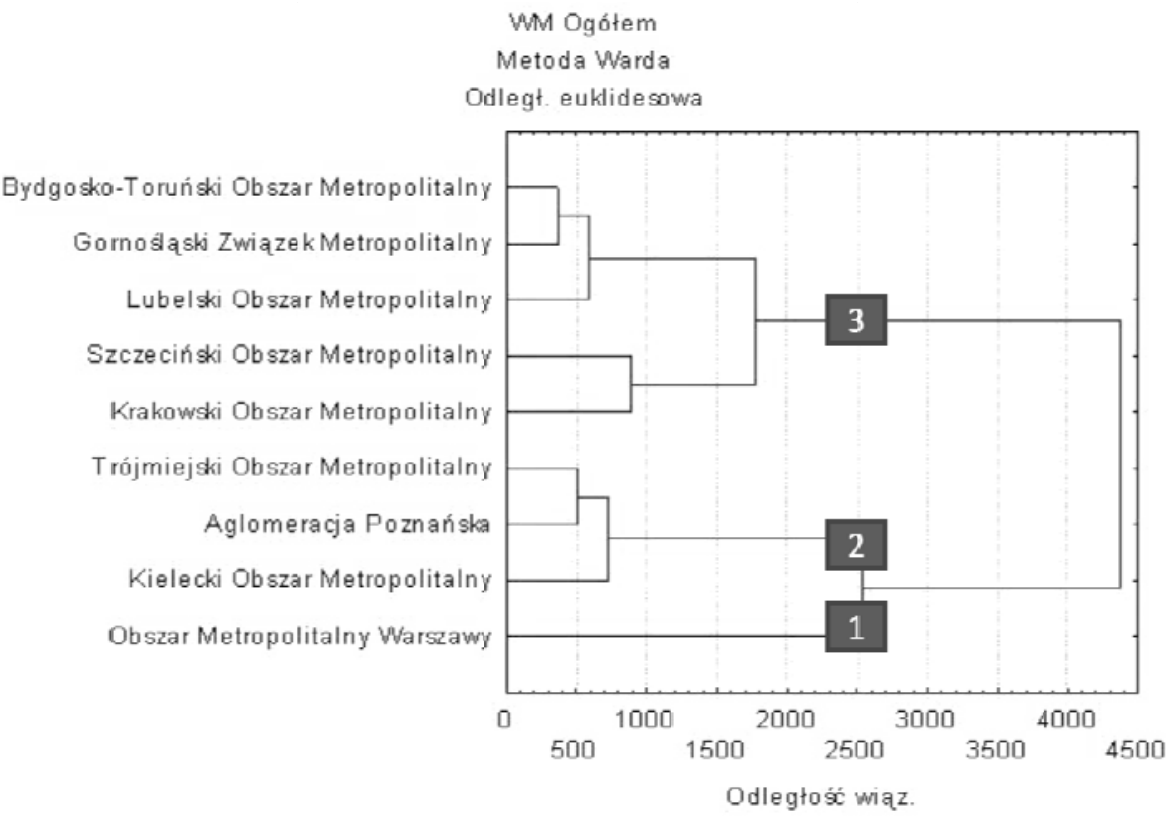

Rysunek 2. Dendrogram skupień obszarów metropolitalnych podobnych pod względem natężenia zjawisk społeczno-gospodarczych na obszarach miejskich w $2010 \mathrm{r}$.

Źródło: opracowanie własne.

Po uwzględnieniu wyżej wymienionych wskaźników aglomeracja przebiegła odmiennie niż $\mathrm{w}$ przypadku rozkładu zjawisk społeczno-gospodarczych w obszarach miejskich i wiejskich (rysunek 2). Znacznie większe były też odległości między skupieniami. Biorąc pod uwagę przebieg aglomeracji, wydzielono 3 skupienia. Spośród wszystkich analizowanych obszarów metropolitalnych zdecydowanie od pozostałych wyróżniały się obszary miejskie Obszaru Metropolitalnego Warszawy. Od pozostałych skupień odróżniała go najniższa gęstość zaludnienia, niższe od średniej dla analizowanych obszarów wartości destymulant obrazujących sytuację na rynku pracy ( $\mathrm{w}$ tym udział bezrobotnych w ludności w wieku produkcyjnym w \% (2B), bezrobotni na 1000 mieszkańców (2C)), bardzo wysoki wskaźnik przedsiębiorczości (podmioty wpisane na 10 tys. ludności (2D), oraz niemal dwukrotnie wyższe niż w skupieniu 3 dochody własne na 1 mieszkańca w zł (3D) - tabela 2. 
Tabela 2. Model średnich arytmetycznych skupień obszarów metropolitalnych podobnych pod względem natężenia zjawisk społeczno-gospodarczych na obszarach miejskich w $2010 \mathrm{r}$.

\begin{tabular}{cccccccccccccc}
\hline & 1A & 1B & 2A & 2B & 2C & 2D & 2E & 2F & $3 \mathrm{~A}$ & $3 \mathrm{~B}$ & $3 \mathrm{C}$ & $3 \mathrm{D}$ & $3 \mathrm{E}$ \\
\hline 1 & 981,5 & 56,1 & 374,7 & 4,2 & 26,7 & 1774,9 & 98,7 & 1,0 & 5560,6 & 21,8 & 4903,7 & 3805 & 55,0 \\
2 & 739,1 & 53,4 & 324,4 & 5,4 & 35,1 & 1445,8 & 98,1 & 1,0 & 4536,6 & 25,3 & 4063,7 & 2554,5 & 43,8 \\
3 & 1215,4 & 52,5 & 293,6 & 6,1 & 40,1 & 1239,6 & 97,4 & 0,9 & 3710,2 & 18,9 & 3434,7 & 2062,4 & 44,3 \\
\hline
\end{tabular}

Źródło: obliczenia własne.

Skupienie 2 objęło Trójmiejski Obszar Metropolitalny, Aglomerację Poznańska, Kielecki Obszar Metropolitalny, w których poza gęstością zaludnienia określone wskaźniki przyjmowały wartości zbliżone do średniej dla analizowanych obszarów miejskich w obszarach metropolitalnych. W skupieniu 3 znalazły się obszary metropolitalne (w tym BTOM), w których wskaźniki będące destymulantami: udział bezrobotnych w ludności w wieku produkcyjnym oraz bezrobotni na 1000 mieszkańców, przyjmowały na obszarach miejskich wartości powyżej średniej dla obszarów miejskich w analizowanych obszarach metropolitalnych. Pozostałe natomiast (za wyjątkiem gęstości zaludnienia) przyjmowały wartości poniżej tej średniej. Skupienie $3 \mathrm{w}$ stosunku do skupienia 1 wykazywało niemal o połowę wyższy udział bezrobotnych w ludności w wieku produkcyjnym (2B odpowiednio $6,1 \%$ i 4,2\%) i wskaźnik bezrobotnych na 1000 mieszkańców (2C - odpowiednio 40,1 i 206,7). Jednocześnie $\mathrm{w}$ tym skupieniu dochody własne na 1 mieszkańca w zł (3D) były niemal o połowę niższe niż w skupieniu 1 (odpowiednio 2062,4 zł/1 mieszk. i 3805,0 zł/1 mieszk.). Wartości wskaźników dla obszarów miejskich Bydgosko-Toruńskiego Obszaru Metropolitalnego oscylowały wokół średnich wartości wskaźników w tym skupieniu, przy czym nieco niższe niż średnio były uzyskiwane wskaźniki dotyczące bezrobocia (udział bezrobotnych w ludności w wieku produkcyjnym (2B); wskaźnik bezrobotnych na 1000 mieszkańców (2C)).

Przeprowadzona następnie na obszarach wiejskich analiza podobieństwa wskaźników natężenia obszarów metropolitalnych wykazała odmienny niż w przypadku obszarów miejskich proces aglomeracji, mniejsze były odległości między skupieniami (rysunek 3). 


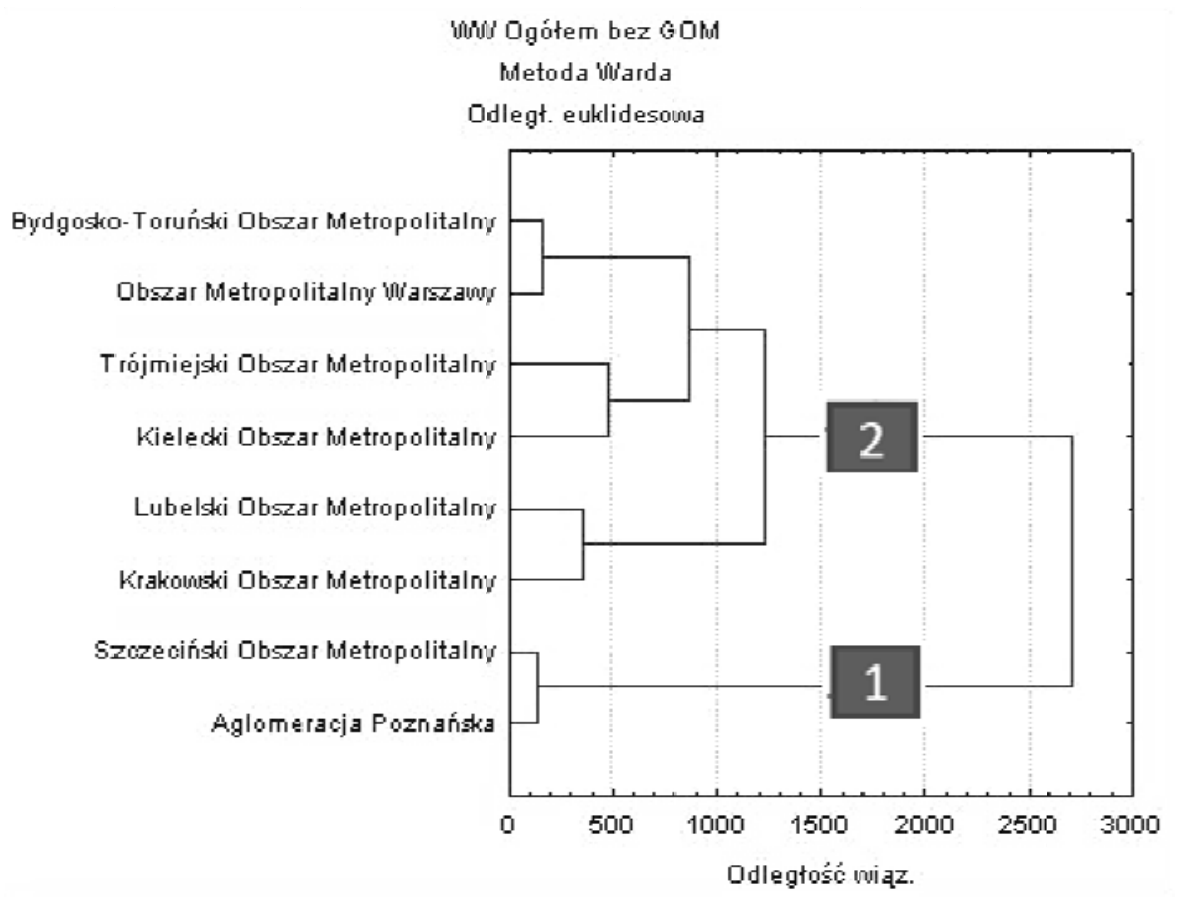

Rysunek 3. Dendrogram skupień obszarów metropolitalnych podobnych pod względem natężenia zjawisk społeczno-gospodarczych na obszarach wiejskich w $2010 \mathrm{r}$.

Źródło: opracowanie własne.

Tabela 3. Model średnich arytmetycznych skupień obszarów metropolitalnych podobnych pod względem natężenia zjawisk społeczno-gospodarczych na obszarach wiejskich w $2010 \mathrm{r}$.

\begin{tabular}{|c|c|c|c|c|c|c|c|c|c|c|c|c|}
\hline $1 \mathrm{~A}$ & $1 B$ & $2 \mathrm{~A}$ & $2 \mathrm{~B}$ & $2 C$ & $2 \mathrm{D}$ & $2 \mathrm{E}$ & $2 \mathrm{~F}$ & $3 \mathrm{~A}$ & $3 \mathrm{~B}$ & $3 C$ & 3D & $3 E$ \\
\hline 174,6 & 50,4 & 216,3 & 5,6 & 37,5 & 1253,2 & 98,2 & 0,8 & 3578,9 & 28,9 & 3151 & 115,7 & 52,6 \\
\hline 285,0 & 56,3 & 125,1 & 7,1 & 45,6 & 793,4 & 97 & 0,5 & 3240,5 & 28,7 & 2863,4 & 1144,7 & 30,4 \\
\hline
\end{tabular}

Źródło: obliczenia własne.

Największe podobieństwo i jednocześnie największą odmienność od pozostałych obszarów wiejskich wykazały: Aglomeracja Poznańska oraz Szczeciński Obszar Metropolitalny. Na przedostatnim poziomie aglomeracji tworzyły one odrębne skupienie (1), w którym analizowane wskaźniki, poza sferą demograficzno-społeczną (w tym zwłaszcza zjawiskiem bezrobocia), przyjmowały wartości wyższe niż średnie dla obszarów wiejskich w anali- 
zowanych metropoliach. Skupienie 2, w którym znalazł się Bydgosko-Toruński Obszar Metropolitalny, charakteryzowało się wyższymi niż średnio dla wszystkich obszarów wiejskich obszarów metropolitalnych wskaźnikami w sferze demograficzno-społecznej oraz mniej korzystną sytuacją na rynku pracy.

\section{PODSUMOWANIE}

Analiza oceny zróżnicowania obszarów metropolitalnych według typologii OECD przeprowadzona za pomocą hierarchicznej metody aglomeracyjnej Warda pozwala stwierdzić, że poziom urbanizacji wyrażony rozkładem cech obrazujących zjawiska społeczno-gospodarcze analizowanych metropolii był bardzo nierównomierny. Wśród analizowanych metropolii wyróżnił się w pełni zurbanizowany Górnośląski Związek Metropolitalny oraz Obszar Metropolitalny Warszawy, w którym koncentracja analizowanych zjawisk na obszarach miejskich była jedną z najwyższych. Metropolią o najniższej koncentracji zjawisk społeczno-gospodarczych na obszarach miejskich był Lubelski Obszar Metropolitalny.

Znacznie większe zróżnicowanie obszarów metropolitalnych obserwuje się, biorąc pod uwagę wskaźniki natężenia. Zauważa się, że proces aglomeracji analizowanych metropolii pod względem wskaźników natężenia przebiegał:

a) odmiennie niż w aglomeracji metropolii pod względem rozkładu cech obrazujących zjawiska społeczno-gospodarcze,

b) odmiennie na obszarach miejskich i wiejskich,

c) wyraźnie od pozostałych dystansował, się tworząc odrębne skupienie, Obszar Metropolitalny Warszawy (zwłaszcza w sferze finansów publicznych oraz w sferze gospodarczej),

d) największe różnice między wydzielonymi skupieniami wystapiły pod względem gęstości zaludnienia i dochodów własnych budżetów gmin.

Bydgosko-Toruński Obszar Metropolitalny pod względem rozkładu zjawisk społeczno-gospodarczych wraz z Szczecińskim, Lubelskim oraz Kieleckim Obszarem Metropolitalnym znalazł się w skupieniu o niższej niż średnio koncentracji potencjału społeczno-gospodarczego na obszarach miejskich. Natomiast pod względem wskaźników natężenia zjawisk społeczno-gospodarczych, zarówno na obszarach miejskich jak i wiejskich, wraz z Szczecińskim i Lubelskim Obszarem Metropolitalnym oraz Górnośląskim Związkiem Metropolitalnym znalazł się w skupieniu, w którym wskaźniki (poza sferą demograficzną oraz wskaźnikami bezrobocia) przyjmowały wartości niższe niż średnio dla analizowanych metropolii. 
Sytuacja w Bydgosko-Toruńskim Obszarze Metropolitalnym odniesiona do obszarów metropolitalnych o najkorzystniejszych wskaźnikach natężenia obrazujących rozwój społeczno-gospodarczy wskazuje, że należy podjąć działania prorozwojowe na rynku pracy i w sferze przedsiębiorczości, które powinny pośrednio przełożyć się na poprawę sytuacji finansowej jednostek samorządu terytorialnego.

\section{LITERATURA}

Chmielewski J. (1995), Studium możliwości rozwoju obszaru metropolitalnego Warszawy. Biuro Zarządu Miasta Stołecznego Warszawy, Urząd Wojewódzki, Warszawa.

Dziewoński K. (1971), Baza ekonomiczna i struktura funkcjonalna miast. Studium rozwoju pojęć, metod i ich zastosowań, [w:] Baza ekonomiczna i struktura funkcjonalna miast, „Prace Geograficzne”, 87, IG PAN, PWN, Warszawa, 9-110.ESPON (2004), ESPON Project 1.1.1. Potentials for polycentric development. Potentials for polycentric development in Europe, NORDREGIO, Sztokholm, http://www.espon.lu/online/documentation/projects/thematic/

Gawryszewski A., Korcelli P., Nowosielska E. (1998), Funkcje metropolitarne Warszawy, Instytut Geografii i Przestrzennego Zagospodarowania Polska Akademia Nauk, Warszawa.

Gocał T., Rakowski W. (1991), Delimitacja regionów i subregionów migracyjnych $w$ zakresie dojazdów do pracy, Szkoła Główna Planowania i Statystyki, Instytut Statystyki i Demografii, Warszawa.

Gorzelak G., Smętkowski M. (2005), Metropolia i jej region w gospodarce informacyjnej, Centrum Europejskich Studiów Regionalnych i Lokalnych UW, Wydawnictwo Naukowe Scholar, Warszawa.

Grabiński T., Sokołowski A. (1984), Z badań nad efektywnościa wybranych procedur taksonomicznych, ZN AE w Krakowie, 181, 63-79.

Grzeszczak J. (1999), Bieguny wzrostu a formy przestrzeni spolaryzowanej, „Prace Geograficzne", 173, IGiPZ PAN, Continuo, Wrocław.

Heffner K. (2011), Funkcje metropolitalne stolic województw Polski Zachodniej, Opole, http://polskazachodnia2020.pl/attachments/article/14/Funkcje\%20metropolitalne\%20st olic\%20wojew\%C3\%B3dztw\%20Polski\%20Zachodniej.pdf.

Jałowiecki B. (1999), Metropolie, Wydawnictwo Wyższej Szkoły Finansów i Zarządzania, Białystok.

Jałowiecki B. (2000), Społeczna przestrzeń metropolii, Wydawnictwo Naukowe Scholar, Warszawa.

Jałowiecki B., Szczepański M. S. (2006), Miasto i przestrzeń w perspektywie socjologicznej, Wydawnictwo Naukowe Scholar, Warszawa.

Jewtuchowicz A. (2004), Procesy metropolizacji a perspektywy rozwoju przestrzeni europejskiej, [w:] Szołek K., Zakrzewska-Półtorak A. (red.), Obszary metropolitalne a rozwój regionalny i lokalny, „Biblioteka Regionalistyki”, 4, 51-59.

Kołodziejski J. (2001), Kształtowanie ładu przestrzennego metropolii w procesie równoważenia rozwoju polskiej przestrzeni. Od tadu przestrzennego do tadu zintegrowanego, [w:] Kołodziejski J., Parseka T., Kształtowanie ładu przestrzennego polskich metropolii w procesie transformacji ustrojowej III RP, „Biuletyn KPZK PAN”, 193, KPZK PAN, Warszawa. 
Korcelli P. (1976), Aglomeracje miejskie w systemach osadniczych. Wybrane hipotezy i perspektywy badawcze, „Przegląd Geograficzny”, 48.

Korcelli P. (1981), Regiony miejskie w systemie osadniczym Polski, [w:] K. Dziewoński, P. Koreclli (red.) Studia nad migracjami i przemianami systemu osadniczego w Polsce, „Prace Geograficzne”, 140, IGiPZ PAN, Warszawa, 189-212.

Korcelli P., Potrykowska, A., Bodzak D. (1981), Układ przestrzenny i wspótzależności ośrodków dojazdów do pracy, [w:]: Dziewoński, K., Korcelli. P., Studia nad migracjami i przemianami systemu osadniczego w Polsce, „Prace Geograficzne”, 140, IGiPZ PAN, Warszawa, 213-233.

Krajowa Strategia Rozwoju Regionalnego 2010-2020: Regiony, Miasta, Obszary wiejskie, MRR, 2010, Warszawa.

Kuciński K. (1990), Podstawy teorii regionu ekonomicznego, Państwowe Wydawnictwo Naukowe, Warszawa.

Maik W. (1976), Założenia i zastosowanie koncepcji zespołów osadniczych, „Przegląd Geograficzny", 48(2), 235-251.

Maik W. (2010), Bydgosko-Toruński Obszar Metropolitalny jako czynnik rozwoju i integracji województwa kujawsko-pomorskiego, [w:] S. Ciok, P. Migoń (red.), Przekształcenia struktur regionalnych. Aspekty społeczne, ekonomiczne i przyrodnicze, Uniwersytet Wrocławski, Wrocław, 65-73.

Markowski T., Marszał T. (2006), Metropolie, obszary metropolitalne, metropolizacja. Problemy i pojęcia podstawowe, PAN, Warszawa.

Rykiel Z. (1985), Zagadnienia regionalnych systemów osadniczych, Państwowe Wydawnictwo Ekonomiczne, Warszawa.

Smętkowski M. (2007), Delimitacja obszarów metropolitalnych - nowe spojrzenie, [w:] Grzelak G., Tucholska A. (red.), Rozwój, region, przestrzeń, Ministerstwo Rozwoju Regionalnego, EUROREG, Warszawa.

Smętkowski M., Jałowiecki B., Gorzelak G. (2008), Obszary metropolitalne w Polsce: Problemy rozwojowe i delimitacja (Diagnoza problemów rozwoju obszarów metropolitalnych i rekomendacja delimitacji obszarów metropolitalnych $w$ Polsce), Raport Centrum Europejskich Studiów Regionalnych i Lokalnych (EUROREG), Uniwersytet Warszawski, Warszawa.

Swianiewicz P., Klimska U., (2005), Społeczne i polityczne zróżnicowanie aglomeracji $w$ Polsce - waniliowe centrum, mozaika przedmieść, „Prace i Studia Geograficzne”, $35,45-70$

Śleszyński P. (2012), Delimitacja miejskich obszarów funkcjonalnych stolic województw, Ekspertyza wykonana dla Ministerstwa rozwoju Regionalnego, Warszawa.

Trafas K., Zborowski A. (2003), Krakowski Obszar Metropolitalny - metropolitalne funkcje Krakowa, Opracowanie dla Urzędu Marszałkowskiego, Kraków.

Uchwała Nr 239 Rady Ministrów z dnia 13 grudnia 2011 r. w sprawie przyjęcia Koncepcji Przestrzennego Zagospodarowania Kraju 2030.

Zborowski A. (2002), Commuting in southern Poland in the period of system transformations, „Biuletyn Geograficzny”, 1, 133-146. 


\title{
STATISTICAL VIEW OF BYGDOSZCZ-TORUŃ METROPOLITAN AREA COMPARED TO OTHER METROPOLITAN AREAS IN POLAND BY OECD TYPOLOGY
}

\begin{abstract}
$\mathrm{A} b \mathrm{str}$ a c t. The main aim of the article is present delimitation and diversity of metropolitan areas in Poland in the field of demographic, social and economic issues, with particular emphasis on the Bydgoszcz-Torun Metropolitan Area. To assess internal diversity of metropolitan area in Poland there was used OECD typology - its allow in terms of functional units show the scale of suburbanization processes.
\end{abstract}

K e y w o r d s: metropolitan area, rural area, urban area. 
